\title{
KONTROWERSJE POLSKIEJ POLITYKI ENERGETYCZNEJ W KONTEKŚCIE REALIZACJI WYMOGÓW UNIJNYCH
}

\begin{abstract}
WSTĘP
Jednym z koniecznych warunków zrealizowania koncepcji i celów zrównoważonego rozwoju jest prowadzenie odpowiedniej polityki energetycznej, zwłaszcza w odniesieniu do energii elektrycznej. Zagadnienia zapewnienia zaopatrzenia $\mathrm{w}$ energię i zabezpieczenia jej nośników określają realne szanse rozwojowe w przyszłości. Dlatego opracowano politykę energetyczną zarówno na poziomie Unii Europejskiej, jak i krajów członkowskich. Polska polityka energetyczna uwzględnia wymogi polityki unijnej, ale specyfika naszej gospodarki i posiadane zasoby surowców energetycznych wywołują pewne problemy z jej realizacją. $Z$ tego względu zasadniczym celem opracowania jest pokazanie kontrowersji związanych $\mathrm{z}$ realizacją polskiej polityki energetycznej w kontekście istniejących uwarunkowań. Najpierw syntetycznie przedstawiono najważniejsze założenia unijnej polityki energetycznej, a następnie przeanalizowano wybrane możliwości realizacji celów polityki energetycznej, zwłaszcza zapewnienia bezpieczeństwa energetycznego. Pozwoliło to wskazać działania, które ułatwią realizację zarówno polskiej, jak i unijnej polityki energetycznej.
\end{abstract}

\section{NAJWAŻNIEJSZE ZAŁOŻENIA EUROPEJSKIEJ POLITYKI ENERGETYCZNEJ}

W 2006 roku przedstawiono cele szczegółowe europejskiej polityki energetycznej (zob. tabela 1) zorientowanej na zrównoważony rozwój energetyki, za- 
warte w tzw. Zielonej Księdze. W tytule tego dokumentu podkreślono, że rozwój energetyki powinien się opierać na koncepcji trwałego i zrównoważonego rozwoju. Wynikało to z zastosowania zapisów Strategii Lizbońskiej, a w szczególności Strategii zrównoważonego rozwoju Unii Europejskiej, które zakładały wdrażanie koncepcji zrównoważonego rozwoju do wszystkich polityk sektorowych. Takie odniesienie jest również w nowym dokumencie Europa 2020. Strategia na rzecz inteligentnego i zrównoważonego rozwoju. Strategia ta opiera się na trzech priorytetach, a jednym $z$ nich jest rozwój zrównoważony (wspieranie gospodarki efektywniej korzystającej z zasobów, bardziej przyjaznej środowisku i bardziej konkurencyjnej). Cel ten ma być realizowany m.in. za pomocą projektu „Europa efektywnie korzystająca z zasobów”. Jest to projekt na rzecz uniezależnienia wzrostu gospodarczego od wykorzystania zasobów, przejścia na gospodarkę niskoemisyjną, większego wykorzystania odnawialnych źródeł energii, modernizacji transportu oraz propagowania efektywności energetycznej.

Tabela 1. Szczegółowe cele europejskiej polityki energetycznej

\begin{tabular}{|c|c|c|}
\hline SPODARCZA & BEZPIECZEŃSTWO ENERGETYCZNE & ZRÓWNOWAŻONY ROZWÓ」 \\
\hline $\begin{array}{l}\text { - stworzenie konkurencyjnego we- } \\
\text { wnętrznego rynku energii (m.in. } \\
\text { poprzez poprawę konkurencyjno- } \\
\text { ści przedsiębiorstw z UE) i uzy- } \\
\text { skanie korzyści dla konsumentów } \\
\text { związanych z otwarciem rynków } \\
\text { energii elektrycznej i gazu } \\
\text { - utrzymanie pozycji Europy jako } \\
\text { czołowego regionu pod wzglę- } \\
\text { dem rozwoju nowoczesnych } \\
\text { technologii energetycznych } \\
\text { - poprawa konkurencyjności zwią- } \\
\text { zanej z produkcją czystej energii } \\
\text { - łagodzenie wpływu wzrostu mię- } \\
\text { dzynarodowych cen energii na } \\
\text { gospodarkę UE i dobrobyt jej } \\
\text { obywateli }\end{array}$ & \begin{tabular}{|} 
- zahamowanie wzrostu popytu na energię \\
(m.in. przez wzrost wydajności energetycz- \\
nej), dywersyfikacja źródeł i kanałów do- \\
staw importowanych nośników energii oraz \\
wykorzystanie wewnętrznych, w tym odna- \\
wialnych, źródeł energii \\
- stworzenie ramowych zachęt do inwestycji \\
odpowiadających rosnącemu popytowi we- \\
wnętrznemu UE na energię \\
- lepsze przygotowanie UE do reagowania \\
w przypadku wystąpienia zakłóceń i kryzy- \\
sów w dostawach energii \\
- wsparcie dążenia europejskich przedsię- \\
biorstw do uzyskania dostępu do zasobów \\
nośników energii na świecie \\
- zapewnienie wszystkim obywatelom \\
i przedsiębiorstwom dostępu do energii
\end{tabular} & $\begin{array}{l}\text { - rozwój konkurencyjnych źró- } \\
\text { deł energii odnawialnej, ba- } \\
\text { dania i rozwój w zakresie } \\
\text { niskoemisyjnych, niskowę- } \\
\text { glowych technologii energe- } \\
\text { tycznych oraz alternatywnych } \\
\text { paliw wykorzystywanych } \\
\text { w transporcie, a także wspie- } \\
\text { ranie innowacji w tym zakre- } \\
\text { sie } \\
\text { - ograniczanie wzrostu popytu } \\
\text { na energię w Europie } \\
\text { - przywództwo w ogólnoświa- } \\
\text { towych staraniach mających } \\
\text { na celu powstrzymanie zmian } \\
\text { klimatycznych oraz poprawę } \\
\text { jakości lokalnego powietrza }\end{array}$ \\
\hline
\end{tabular}

Źródło: Europejska strategia na rzecz zrównoważonej, konkurencyjnej i bezpiecznej energii. Zielona Księga. Wersja ostateczna, Komisja Europejska, Bruksela 8.03.2006, COM 105.

W nowej wizji energetyki kluczowe znaczenie ma kwestia zmian klimatycznych oraz zapewnienie równowagi między celami ochrony środowiska naturalnego, konkurencyjnością i bezpieczeństwem dostaw energii. Ta triada celów stworzyła nowe wyzwania i standardy optymalnej alokacji wszystkich potencjalnych nośników energii w procesie transformacji do gospodarki „ni- 
skowęglowej” i niskoemisyjnej, o zdywersyfikowanych źródłach pozyskiwania nośników energii, nastawionej na wzrost efektywności i wydajności energetycznej, gwarantującej wzrost dobrobytu społecznego. Cele te zostały powtórzone w Europejskiej polityce energetycznej.

Największą zaletą przedstawionej w 2007 roku polityki energetycznej było połączenie zagadnień rozwoju energetyki i ochrony środowiska naturalnego $^{1}$. W tym dokumencie Wspólnota została zobowiązana do:

- zmniejszenia o co najmniej 20\% emisji gazów cieplarnianych w UE do 2020 roku w porównaniu z rokiem 1990 (ta redukcja miałaby się zwiększyć do 30\% w przypadku podjęcia nowych zobowiązań przez inne kraje uprzemysłowione);

- zwiększenia udziału energii pozyskiwanej z odnawialnych źródeł energii (OZE) do 20\% w całkowitym zużyciu energii do 2020 roku, w tym celu dotyczącego 10\% udziału biopaliw, a 5,75\% w $2010 \mathrm{roku}^{2}$;

- zmniejszenia zużycia energii w UE o $20 \%$ w porównaniu z prognozami na 2020 rok.

Ten zestaw celów, określany nazwą „3×20”, jest najbardziej ambitnym przedsięwzięciem, zapowiadającym długofalowe i kompleksowe procesy przemian polityki energetycznej. Łączy on cele ekonomiczne, ekologiczne i energetyczne.

Propozycje przedłożone w Europejskiej polityce energetycznej zostały uwzględnione w pięciu aktach prawnych wchodzących w skład tak zwanego pakietu energetyczno-klimatycznego ${ }^{3}$. Są to następujące dokumenty:

- dyrektywa ramowa dotycząca promocji wykorzystania odnawialnych źródeł energii (COM, 2008/019);

- decyzja Parlamentu Europejskiego i Rady w sprawie starań podejmowanych przez państwa członkowskie zmierzających do ograniczenia emisji gazów cieplarnianych do 2020 roku; przewidziano tu przyznanie poszczególnym państwom zróżnicowanych celów redukcji (wahających się od $-20 \%$ do $+20 \%)$ i przyjęcia w sektorach nieobjętych dotychczas systemem EU ETS, takich jak budownictwo, transport, rolnictwo czy gospodarka odpadami, do 2020 roku zobowiązania redukcji emisji o 10\% w stosunku do 2005 roku;

${ }^{3}$ Europejska polityka energetyczna, Komunikat Komisji do Rady Europy i Parlamentu Europejskiego, Komisja Europejska, Bruksela 10.01.2007, COM 1 wersja ostateczna 2007.

${ }^{4}$ Przedtem w dyrektywie 2001/77/WE założono 12\% udział energii ze źródeł odnawialnych do 2010 roku.

${ }_{5}$ Pakiet klimatyczno-energetyczny. Analityczna ocena propozycji Komisji Europejskiej, Urząd Komitetu Integracji Europejskiej, Departament Polityki Integracyjnej, Warszawa 2008. 
- dyrektywa Parlamentu Europejskiego i Rady zmieniająca dyrektywę 2003/87/WE w sprawie udoskonalania i rozszerzania wspólnotowego systemu handlu uprawnieniami do emisji gazów cieplarnianych (chodzi o zastąpienie od 2013 roku narodowych limitów przez limity branżowe dla całej UE oraz likwidację arbitralnej początkowej alokacji certyfikatów w sektorze energetyki i zastąpienie jej przez aukcję);

- dyrektywa Parlamentu Europejskiego i Rady w sprawie geologicznego magazynowania dwutlenku węgla (CCS), zakładająca wybudowanie 12 instalacji demonstracyjnych wykorzystujących technologię CCS, zmieniająca dyrektywy Rady 85/337/EWG, 96/61/WE, 2000/60/WE, 2001/80/WE, 2004/35/WE, 2006/12/WE i rozporządzenie (WE) nr 1013/2006;

- wytyczne w zakresie udzielania przez państwo pomocy publicznej dotyczącej ochrony środowiska, pozwalają one na udzielenie pomocy prywatnym inwestycjom na energetykę odnawialną i poprawę efektywności energetycznej, to znaczy na oszczędność energii, na prostszych zasadach niż dotychczas.

Obok dokumentów wchodzących w skład pakietu klimatyczno-energetycznego istnieje szereg innych dokumentów UE dotyczących energetyki, ale nie będą tu one omawiane ze względu niewielką objętość opracowania. Wspomnieć jednak należy o tych najnowszych, a istotnych z punktu widzenia tematu opracowania. Jednym z nich jest dokument Energia 2020. Strategia na rzecz konkurencyjnego, zrównoważonego i bezpiecznego sektora energetycznego ${ }^{4}$, opublikowany 10 listopada 2010 roku. Jego treść należy uznać za podstawową strategię rozwoju energetyki. Wynika to z jednej strony ze szczegółowości zawartych zapisów, a $z$ drugiej $-\mathrm{z}$ ich ogólnego charakteru. Konsekwencją tego jest jasne określenie kierunków i zadań, jakie mają być zrealizowane w ciągu najbliższych 10 lat, ale bez zagłębiania się w szczegóły.

Istotne jest, że tekst tej strategii został napisany jako element wspólnej polityki energetycznej UE, opierającej się - jak już wspomniano - na założeniach zawartych w Zielonej Księdze i Strategii Lizbońskiej. Cele na najbliższą dekadę zostały poprzedzone ogólną analizą sytuacji w europejskiej energetyce. Podkreślono w niej nie tylko zalety europejskich systemów (np. pozyskiwanie około 45\% energii elektrycznej z niskoemisyjnych źródeł), ale przede wszystkim wskazano wady. Można do nich zaliczyć przestarzałe moce produkcyjne (do 2020 roku około 1/3 zdolności do wytwarzania energii powinna być zastąpiona nowymi instalacjami, około 30 tys. $\mathrm{km}$ linii przesyłowych wymaga wymiany), ograniczenia dla konsumentów w dostępie do dystrybutorów

\footnotetext{
${ }^{6}$ Energia 2020. Strategia na rzecz konkurencyjnego, zrównoważonego i bezpiecznego sektora energetycznego, Komisja Wspólnot Europejskich, KOM(2010)639, wersja ostateczna.
} 
energii, zbyt opieszałe wprowadzanie projektów z zakresu efektywności energetycznej oraz wyzwania $\mathrm{z}$ zakresu bezpieczeństwa dostaw.

Kolejnym dokumentem istotnym z politycznego punktu widzenia dla rozwoju europejskiej energetyki jest przedstawiony w 28 marca 2011 roku Plan na rzecz zbudowania niskoemisyjnej gospodarki do roku 2050 (tzw. energetyczna mapa drogowa). W dokumencie tym powtórzono zapisy o konieczności takiego rozwoju sektora, aby zredukować emisję gazów cieplarnianych o 80-95\% w 2020 roku w stosunku do 1990 roku. Nadal są to tylko hasła, z tym, że umieszczono je w szerszej strategii całościowego rozwoju sektora, a nie tylko w pakiecie klimatyczno-energetycznym.

Generalnie, zapisy obu nowych dokumentów nie mają jeszcze charakteru wiążącego, ale stanowią podstawę do dalszy rozmów i ustaleń w ramach Unii Europejskiej. Pozytywne w nich jest to, że podkreślają problemy stojące przed unijną energetyką, a wymagające konsekwentnych działań.

Wszystkie państwa członkowskie Unii Europejskiej są zobligowane do uwzględnienia wymogów unijnej polityki energetycznej w krajowej polityce energetycznej oraz do realizacji jej celów i wytycznych w kontekście zrównoważonego rozwoju, zwłaszcza w odniesieniu do zagadnień ochrony środowiska naturalnego, gospodarki niskoemisyjnej i bezpieczeństwa energetycznego. Realizacja celów i wytycznych polityki energetycznej w tych obszarach wymaga konkretnych działań ze strony podmiotów tworzących sektor energetyczny. Jednocześnie działania te, jak i zaplanowane sposoby realizacji celów, stwarzają pewne problemy i wywołują kontrowersje na różnych płaszczyznach. $Z$ tego względu podjęto próbę wskazania tych problemów i kontrowersji na gruncie polskim.

\section{WYBRANE KONTROWERSJE W POLSKIEJ POLITYCE ENERGETYCZNEJ}

Podstawowym dokumentem przedstawiającym strategię państwa w zakresie rozwoju energetyki, zarówno w krótkiej jak i dłuższej perspektywie, jest Polityka energetyczna Polski do 2030 roku5. Określono w niej następujące podstawowe kierunki polityki energetycznej:

- poprawa efektywności energetycznej;

- wzrost bezpieczeństwa dostaw paliw i energii;

- dywersyfikacja struktury wytwarzania energii elektrycznej poprzez wdrożenie energetyki jądrowej;

7 Polityka energetyczna Polski do 2030 roku. Ministerstwo Gospodarki. Załącznik do uchwały nr 202/2009 Rady Ministrów, Warszawa 10.11.2009. 
- rozwój wykorzystania odnawialnych źródeł energii, w tym biopaliw;

- rozwój konkurencyjnych rynków paliw i energii;

- ograniczenie oddziaływania energetyki na środowisko.

Przyjęte kierunki polityki energetycznej są w znacznym stopniu współzależne: poprawa efektywności energetycznej ogranicza wzrost zapotrzebowania na paliwa i energię, przyczyniając się do zwiększenia bezpieczeństwa energetycznego na skutek zmniejszenia uzależnienia od importu. Dodatkowo przyczynia się do ograniczenia wpływu energetyki na środowisko poprzez redukcję emisji zanieczyszczeń. Podobne efekty przynosi rozwój wykorzystania odnawialnych źródeł energii, nowych technologii węglowych oraz wprowadzenie energetyki jądrowej. Realizując działania zgodnie $\mathrm{z}$ tymi kierunkami polityka energetyczna będzie dążyła do wzrostu bezpieczeństwa energetycznego kraju przy zachowaniu zasady zrównoważonego rozwoju oraz wypełnienia zobowiązań wynikających z dokumentów unijnych.

Specyfika polskiej gospodarki i posiadane zasoby surowców energetycznych wywołują pewne problemy $\mathrm{z}$ realizacją przyjętych założeń i zobowiązań unijnych. Dlatego przeanalizowano wybrane możliwości realizacji celów polityki energetycznej, zwłaszcza zapewnienia bezpieczeństwa energetycznego, w kontekście istniejących uwarunkowan, które wzbudzają pewne kontrowersje.

Zgodnie z ustawą Prawo energetyczne, bezpieczeństwo energetyczne to „stan gospodarki umożliwiający pokrycie bieżącego zapotrzebowania odbiorców na paliwa i energię w sposób technicznie uzasadniony, przy zachowaniu wymagań ochrony środowiska". W miarę upływu czasu i zmian dokonywanych $\mathrm{w}$ unijnej polityce energetycznej definicja ta uległa rozszerzeniu. Wprowadzono do niej takie pojęcia jak: bezpieczeństwo dostaw, bezpieczeństwo pracy sieci elektroenergetycznej, równoważenie dostaw energii elektrycznej z zapotrzebowaniem na tę energię, zagrożenie bezpieczeństwa dostaw energii elektrycznej. Generalnie jednak chodzi o zapewnienie możliwości zaspokojenia potrzeb energetycznych użytkowników energii w odpowiedni sposób i po przystępnej cenie.

Podstawową kwestią jest więc zapewnienie dostosowania podaży energii do popytu na nią. W Polsce na koniec 2008 roku całkowite zużycie energii paliwa umownego wynosiło $98,3 \mathrm{mln}$ ton, a łączny deficyt energetyczny (uzupełniany importem) wynosił $19,9 \%{ }^{7}$. W porównaniu $\mathrm{z}$ innymi państwami UE jest to wskaźnik relatywnie niski, ale i tak stanowi on pewien problem, zmuszając do poszukiwania nośników energii poza krajem. Deficyt ten może w przyszłości się pogłębić, gdy wyczerpią się krajowe zasoby kopalin. Wpraw-

${ }^{8}$ Ustawa z dnia 10.04.1997 r., Dz.U. 2006, Nr 89, poz. 625 z późn. zm.

9 Europe's Energy Portal, accessed: www.energy.eu (data pobrania 10.10.2011). 
dzie zasoby węgla (kamiennego i brunatnego) są względnie duże, ale pozostałych nośników jest zbyt mało w stosunku do potrzeb (zob. tabela 2), import więc będzie konieczny ${ }^{8}$. $Z$ tego względu niezbędne jest opracowanie bilansu energetyczno-ekonomicznego, który będzie obejmował nie tylko dane geologiczne o zasobach, ale również zmiany cen i dostępności nośników (a w konsekwencji cen energii dla użytkowników) w długim horyzoncie czasowym oraz koszty budowy odpowiedniej infrastruktury energetycznej z uwzględnieniem kierunku dostaw poszczególnych nośników ${ }^{9}$. Jest to niezmiernie istotne w kontekście dywersyfikacji źródeł i nośników energii i związanego z tym bezpieczeństwa energetycznego. Dotychczas taki łączny bilans nie został przygotowany.

Tabela 2. Zasoby ważniejszych kopalin w Polsce w 2009 r. (w mln t; gaz w mld m³)

\begin{tabular}{|l|c|c|c|}
\hline \multirow{2}{*}{ RodZAJ } & \multicolumn{2}{|c|}{ ZASOBY BILANSOWE Ztóż GEOLOGICZNIE UDOKUMENTOWANE } & \multirow{2}{*}{ WYDOBYCIE } \\
\cline { 2 - 3 } & OGótem & W TYM ZAGOSPODAROWANE & \\
\hline Ropa naftowa & 25,88 & 25,30 & 0,66 \\
\hline Gaz ziemny & 146,81 & 119,83 & 5,84 \\
\hline Węgiel brunatny & 14858,96 & 1748,86 & 57,06 \\
\hline Węgiel kamienny & 44229.47 & 16948,13 & 70,90 \\
\hline
\end{tabular}

Źródło: Ochrona środowiska, GUS, Warszawa 2010, s. 122.

Na konieczność zadbania o odpowiednią do potrzeb ilość nośników energii i odpowiednie moce wytwórcze wskazuje również dynamika zużycia energii elektrycznej w relacji do dynamiki produkcji. Wprawdzie dotychczas (tabela 3) wielkość produkcji energii elektrycznej pokrywała rosnące jej zużycie, ale przy dużo większej dynamice zużycia energii elektrycznej w stosunku do dynamiki produkcji może się to stać trudne. Rosnące rozbieżności między popytem na energię elektryczną a jej podażą wskazują m.in. na konieczność zwiększenia efektywności energetycznej, jak i uzupełniania mocy wytwórczych systemu energetycznego poprzez import energii oraz rozbudowę infrastruktury energetycznej. Pamiętać jednak należy, że import energii nie powinien nadmiernie się zwiększać (nie można dopuścić do sytuacji nadwyżki importu energii elektrycznej nad eksportem), gdyż mogłoby to zagrozić bezpieczeństwu energetycznemu kraju z powodu nadmiernego uzależ-

${ }^{10}$ Chyba, że spełni się „sen o gazie łupkowym”.

11 Por. m.in. A. Pawłowski, Uwarunkowania bezpieczeństwa energetycznego Polski a rozwój zrównoważony, [w:] D. Kiełczewski (red.), Implementacyjne aspekty wdrażania zrównoważonego rozwoju, Wyd. Wyższej Szkoły Ekonomicznej w Białymstoku, Białystok 2011. 
nienia od źródeł zewnętrznych. W tej sytuacji należy zatem zadbać o rozwój krajowej infrastruktury energetycznej w szerokim rozumieniu, czyli m.in. by polski sektor energetyczny był w stanie wyprodukować odpowiednią ilość energii $\mathrm{i}$ to zgodnie $\mathrm{z}$ wymogami unijnymi (zwłaszcza w zakresie ochrony środowiska).

Tabela 3. Produkcja i zużycie energii elektrycznej brutto w Polsce w latach 2000-2009

\begin{tabular}{|l|c|c|c|c|c|c|c|c|c|c|}
\hline \multicolumn{1}{|c|}{ Rok } & 2000 & 2001 & 2002 & 2003 & 2004 & 2005 & 2006 & 2007 & 2008 & 2009 \\
\hline $\begin{array}{l}\text { Produkcja energii elek- } \\
\text { trycznej [TWh] }\end{array}$ & 145,18 & 145,61 & 144,12 & 151,63 & 154,15 & 156,93 & 161,96 & 159,45 & 155,57 & 150,91 \\
\hline $\begin{array}{l}\text { Dynamika } \\
\text { Rok 2000 = 100 }\end{array}$ & 100 & 100,3 & 99,3 & 104,4 & 106,2 & 108,1 & 111,6 & 109,8 & 107,2 & 103,9 \\
\hline $\begin{array}{l}\text { Zużycie energii elek- } \\
\text { trycznej brutto [TWh] }\end{array}$ & 128,81 & 138,88 & 137,05 & 141,47 & 144,86 & 145,74 & 150,70 & 154,10 & 154,75 & 148,71 \\
\hline $\begin{array}{l}\text { Dynamika } \\
\text { Rok 2000 = 100 }\end{array}$ & 100 & 107,8 & 106,4 & 109,8 & 112,5 & 113,1 & 117,0 & 119,6 & 120,1 & 115,4 \\
\hline
\end{tabular}

Źródło: opracowanie na podstawie: B. Zaporowski, Analiza kosztów wytwarzania energii elektrycznej, t. 11, z. 1, IGSMiE PAN, Kraków 2008, s. 533; dane GUS oraz http//www.pse-operator.pl. (data pobrania 12.12.2010 r.).

Dodatkowym potwierdzeniem konieczności zwiększenia mocy wytwórczych polskiego sektora energetycznego (poprzez wykonanie inwestycji) jest przewidywany deficyt energii elektrycznej ${ }^{10}$. Jak widać w tabeli 4, w 2030 ro$\mathrm{ku}$ - przy rosnącym zużyciu energii elektrycznej - prognozowana wymagana moc osiągalna będzie prawie trzykrotnie większa od przewidywanej mocy osiągalnej z instalacji obecnie istniejących. Sektor energetyczny, bez odpowiednich inwestycji, nie będzie w stanie pokryć krajowego popytu na energię elektryczną.

Tabela 4. Wymagane nowe moce wytwórcze w systemie elektroenergetycznym w latach 2015-2030

\begin{tabular}{|l|c|c|c|c|}
\hline \multicolumn{1}{|c|}{ Wielkość } & 2015 & 2020 & 2025 & 2030 \\
\hline Przewidywane zużycie energii elektrycznej brutto [TWh] & 180,558 & 199,351 & 220,351 & 243 \\
\hline Wymagana moc osiągalna (zainstalowana) [MW] & 36700 & 40300 & 44500 & 49000 \\
\hline $\begin{array}{l}\text { Przewidywana moc osiągalna w istniejących w 2008 r. } \\
\text { jednostkach wytwórczych w kraju [MW] }\end{array}$ & 31200 & 29900 & 22300 & 17100 \\
\hline Wymagane nowe inwestycje w kraju [MW] & 5500 & 9400 & 21200 & 30900 \\
\hline
\end{tabular}

Źródło: B. Zaporowski, Analiza kosztów wytwarzania energii..., op. cit., s. 533.

${ }^{12}$ Według Z. Kasztelewicza, wymagane nowe inwestycje w kraju mogą wynosić nawet 45 tys. MW. Zob.: Z. Kasztelewicz, Zasoby wegla brunatnego w Polsce i perspektywy ich wykorzystania, „Polityka Energetyczna”, t. 11, z. 1, IGSMiE PAN, Kraków 2008, s. 184. 
Tymczasem w Polsce większość wyprodukowanej energii elektrycznej pochodzi z elektrowni zawodowych opalanych węglem. Udział tego paliwa w produkcji energii elektrycznej w Polsce wynosi 93,5\%11. Z 20 konwencjonalnych elektrowni, pięć (Bełchatów, Turów, Pątnów, Adamów i Konin) opalanych jest węglem brunatnym i wytwarzają one 54,1 TWh (około 46\%) energii elektrycznej rocznie (tabela 5). Pozostałe są opalane węglem kamiennym i wytwarzają około 54\% ogółu energii pochodzącej z konwencjonalnych elektrowni. Pierwszych dziesięciu producentów dysponuje mocą 19931 MW energii elektrycznej, co stanowi 81,15\% potencjału mocy w Polsce.

Warto zwrócić uwagę na wiek polskich elektrowni. Najczęściej budowano je w latach 1960-1970. Nieliczne jednostki wytwórcze powstawały po tym okresie. Najnowsza Elektrownia Opole zbudowana w latach 1993-1997, pomimo zastosowania względnie nowych technologii, jest wymieniana w dokumentach unijnych, jako jednostka również wymagająca modernizacji. Nieliczne elektrownie zostały zmodernizowane w stopniu zapewniającym utrzymanie obowiązujących standardów środowiskowych, a pozostałe wymagają modernizacji. Oznacza to, że niezbędne jest przeprowadzenie odpowiednich, bardzo kosztownych inwestycji, na które elektrowniom brakuje środków pieniężnych. Bez modernizacji elektrownie nie będą mogły funkcjonować, a $z$ czasem nawet zapewnić odpowiedniej podaży energii. Polska jako kraj nie może sobie na to pozwolić. Państwo z kolei, nawet gdyby miało możliwości, nie może udzielić pomocy finansowej tym elektrowniom, bo naruszałoby to unijne przepisy o konkurencyjności przedsiębiorstw. W takiej sytuacji chcąc m.in. zapewnić bezpieczeństwo energetyczne oraz stworzyć konwencjonalnym elektrowniom możliwość zarobienia środków na modernizację oparto politykę energetyczną na energii wytwarzanej $\mathrm{z}$ dostępnego, relatywnie tańszego nośnika, jakim jest węgiel.

$\mathrm{Z}$ punktu widzenia wymogów unijnych, w tym pakietu klimatyczno-energetycznego, oparcie polskiej polityki energetycznej w większości na produkcji energii $\mathrm{w}$ istniejących konwencjonalnych elektrowniach i dostępnych zasobach surowców energetycznych (głównie węgla brunatnego i kamiennego) jest sprzeczne m.in. z założeniami o dywersyfikacji źródeł energii, zwiększaniu udziału energii ze źródeł odnawialnych oraz gospodarce niskoemisyjnej związanej z ograniczaniem emisji zanieczyszczeń powietrza. Można jednak powiedzieć, że istnienie tych sprzeczności uzasadnia konieczność przyspieszenia odpowiednich działań (na różnych poziomach) dostosowujących sektor energetyczny do stawianych mu wymogów.

${ }_{13}$ Por.: B. Zaporowski, op. cit., s. 534. Udział węgla w produkcji energii elektrycznej wynosi: w RPA - 93\%, w Australii - 80\%, w Chinach - 78\%, w Izraelu - 71\%, w Kazachstanie - 70\%, w Indiach - 69\%, w Maroku - 69\%, w Czechach - 59\%, w Grecji - 58\%, w USA - 50\%, w Niemczech - 47\% (za: ibidem). 
Tabela 5. Najwięksi producenci energii elektrycznej w Polsce

\begin{tabular}{|c|c|c|c|c|c|c|c|}
\hline LP. & ELEKTROWNIA & $\begin{array}{l}\text { LICZBA KOTŁÓW/ } \\
\text { /LICZBA } \\
\text { TURBOZESPOŁóW }\end{array}$ & $\begin{array}{l}\text { RODZA } \\
\text { PALIWA }\end{array}$ & $\begin{array}{c}\text { ROK URUCHOMIENIA/ } \\
\text { /ROK URUCHOMIENIA } \\
\text { OSTATNIEGO TURBOZESPOLU }\end{array}$ & $\begin{array}{l}\text { Moc } \\
{[\mathrm{MW}]}\end{array}$ & $\begin{array}{c}\text { PRODUKCJA } \\
\text { W } 2005 \text { ROKU } \\
\text { [TWH] }\end{array}$ & $\begin{array}{c}\text { PRODUKCJA } \\
\text { W } 2008 \\
\text { ROKU [TWH] }\end{array}$ \\
\hline 1 & $\begin{array}{l}\text { BOT Elektrownia } \\
\text { Bełchatów SA }\end{array}$ & $12 / 12$ & w.b. & $1981 / 2001$ & 4430 & 29,5 & 28,8 \\
\hline 2 & $\begin{array}{l}\text { Elektrownia Kozie- } \\
\text { nice SA }\end{array}$ & $10 / 10$ & w.k. & $1972 / 1979$ & 2846 & 11,7 & 11,8 \\
\hline 3 & $\begin{array}{l}\text { BOT Elektrownia Tu- } \\
\text { rów SA }\end{array}$ & $9 / 9$ & w.b. & $1962 / 2004$ & 2106 & 13,5 & 12,8 \\
\hline 4 & $\begin{array}{l}\text { Elektrownia Poła- } \\
\text { niec SA }\end{array}$ & $8 / 8$ & w.k. & 1979/1983 & 1800 & 5,0 & 5,0 \\
\hline 5 & $\begin{array}{l}\text { Elektrownia Ryb- } \\
\text { nik SA }\end{array}$ & $8 / 8$ & w.k. & $1972 / 1978$ & 1775 & 10,1 & 9,0 \\
\hline 6 & $\begin{array}{l}\text { Elektrownia Dolna } \\
\text { Odra SA }\end{array}$ & $8 / 8$ & w.k. & 1974/1977 & 1742 & 4,3 & 6,5 \\
\hline 7 & $\begin{array}{l}\text { BOT Elektrownia } \\
\text { Opole SA }\end{array}$ & $4 / 4$ & w.k. & 1993/1997 & 1532 & 8,3 & 7,9 \\
\hline 8 & $\begin{array}{l}\text { PKE SA Elektrownia } \\
\text { Jaworzno III }\end{array}$ & $11 / 11$ & w.k. & 1976/1999 & 1345 & 5,2 & 6,1 \\
\hline 9 & $\begin{array}{l}\text { Elektrownia Pąt- } \\
\text { nów SA }\end{array}$ & $6 / 6$ & w.b. & 1969/1969 & 1200 & 6,7 & 6,7 \\
\hline 10 & $\begin{array}{l}\text { PKE SA Elektrownia } \\
\text { Łaziska }\end{array}$ & $6 / 6$ & w.k. & $1917 / 1972$ & 1155 & 5,5 & 5,5 \\
\hline 11 & $\begin{array}{l}\text { PKE SA Elektrownia } \\
\text { Siersza }\end{array}$ & $6 / 6$ & w.k. & $1962 / 2002$ & 805 & 3,2 & 2,9 \\
\hline 12 & $\begin{array}{l}\text { PKE SA Elektrownia } \\
\text { Łagisza }\end{array}$ & $7 / 7$ & w.k. & $1963 / 1970$ & 710 & 2,8 & 2,3 \\
\hline 13 & $\begin{array}{l}\text { Elektrownia Ostro- } \\
\text { tęka SA }\end{array}$ & $3 / 3$ & w.k. & 1972/1972 & 647 & 2,4 & 2,4 \\
\hline 14 & $\begin{array}{l}\text { Elektrownia Ada- } \\
\text { mów SA }\end{array}$ & $5 / 5$ & w.b. & 1966/1966 & 600 & 3,5 & 3,8 \\
\hline 15 & $\begin{array}{l}\text { Elektrownia Skawi- } \\
\text { na SA }\end{array}$ & $11 / 7$ & w.k. & $1957 / 1961$ & 575 & 2,4 & 2,5 \\
\hline 16 & $\begin{array}{l}\text { Elektrownia Ko- } \\
\text { nin SA }\end{array}$ & $8 / 7$ & w.b. & $1964 / 1964$ & 488 & 1,7 & 2,0 \\
\hline 17 & $\begin{array}{l}\text { Elektrownia Stalowa } \\
\text { Wola SA }\end{array}$ & $6 / 4$ & w.k. & $1939 / 1968$ & 250 & 1,1 & 1,1 \\
\hline 18 & $\begin{array}{l}\text { PKE SA Elektrownia } \\
\text { Halemba }\end{array}$ & $4 / 4$ & w.k. & $1962 / 1963$ & 200 & 0,6 & 0,27 \\
\hline 19 & $\begin{array}{l}\text { PKE SA Elektrownia } \\
\text { Jaworzno II }\end{array}$ & $11 / 11$ & w.k. & 1953/1999 & 198 & 1,0 & 0,89 \\
\hline \multirow[t]{4}{*}{20} & $\begin{array}{l}\text { PKE SA Elektrownia } \\
\text { Blachownia }\end{array}$ & $3 / 3$ & w.k. & $1957 / 1960$ & 158 & 0,5 & 0,55 \\
\hline & $\begin{array}{l}\text { Wszystkie elektro- } \\
\text { wnie }\end{array}$ & $135 / 128$ & - & - & 24562 & 119,0 & 118,81 \\
\hline & $\begin{array}{l}\text { Węgiel brunatny } \\
\text { - w.b. }\end{array}$ & $40 / 39$ & - & - & 8824 & 54,9 & 54,1 \\
\hline & $\begin{array}{l}\text { Węgiel kamienny } \\
\text { - w.k. }\end{array}$ & $95 / 89$ & - & - & 15738 & 64,1 & 64,71 \\
\hline
\end{tabular}

Źródło: opracowanie na podstawie http//energetyka.wnp.pl/elektrownie (data pobrania 10.08.2011). 
Z punktu widzenia wymogów unijnych, w tym pakietu klimatyczno-energetycznego, oparcie polskiej polityki energetycznej w większości na produkcji energii w istniejących konwencjonalnych elektrowniach i dostępnych zasobach surowców energetycznych (głównie węgla brunatnego i kamiennego) jest sprzeczne m.in. z założeniami o dywersyfikacji źródeł energii, zwiększaniu udziału energii ze źródeł odnawialnych oraz gospodarce niskoemisyjnej związanej z ograniczaniem emisji zanieczyszczeń powietrza. Można jednak powiedzieć, że istnienie tych sprzeczności uzasadnia konieczność przyspieszenia odpowiednich działań (na różnych poziomach) dostosowujących sektor energetyczny do stawianych mu wymogów.

Wzrastające zużycie energii elektrycznej w Polsce jest tylko jednym z powodów prowadzenia modernizacji istniejących elektrowni. Inną bardzo ważną przesłanką, nie tylko modernizacji instalacji wytwórczych, ale również budowy nowych bloków energetycznych, jest konieczność sprostania wymogom z zakresu ochrony środowiska określonym przez UE. Nie jest to łatwe, gdy produkcja energii elektrycznej w Polsce jest głównie oparta na spalaniu węgla. Oznacza to bowiem z jednej strony szybką i bezpowrotną utratę posiadanych zasobów węgla, a tym samym rosnące zagrożenie bezpieczeństwa energetycznego $z$ powodu wyczerpywania się dostępnego nośnika energii. Zmusza to również do odpowiedzi na pytanie - co dalej i podjęcia stosownych decyzji przy uwzględnieniu określonych uwarunkowań ekologicznych, ekonomicznych i społecznych ${ }^{12}$. Z drugiej zaś strony wiąże się $\mathrm{z}$ negatywnymi konsekwencjami środowiskowymi powodowanymi - jak wiadomo - zanieczyszczeniami powstającymi przy spalaniu węgla (emisją $\mathrm{CO}_{2}, \mathrm{SO}_{2}, \mathrm{NOx}$, pyłów czy pierwiastków radioaktywnych) oraz odpadami powstającymi przy pozyskiwaniu urobku, które trafiają na składowiska i same w sobie stanowią problem środowiskowy. Biorąc powyższe pod uwagę zaproponowano w Polityce energetycznej następujące działania na rzecz ograniczenia oddziaływania energetyki na środowisko:

- stworzenie systemu zarządzania krajowymi pułapami emisji gazów cieplarnianych i innych substancji;

- wykorzystanie przychodów z aukcji uprawnień do emisji $\mathrm{CO}_{2}$ do wspierania działań ograniczających emisję gazów cieplarnianych;

- wprowadzenie standardów budowy nowych elektrowni w systemie przygotowania do wychwytywania $\mathrm{CO}_{2}$ oraz określenie krajowych możliwości geologicznego składowania tego gazu;

- wykorzystanie technologii CCS (wychwytywania i magazynowania $\mathrm{CO}_{2}$ ) do wspomagania wydobycia ropy naftowej i gazu ziemnego.

12 Decyzja jest tym trudniejsza, że nie ma społecznej akceptacji dla elektrowni atomowych, a z ilość energii pozyskiwana ze źródeł odnawialnych nie będzie w stanie pokryć popytu na nią. 
Wymienione działania nie są jednak realizowane w wymaganym tempie, $\mathrm{w}$ odniesieniu do niektórych $\mathrm{z}$ nich istnieją dopiero pewne "przymiarki”"13. Kończą się również ustalone w Traktacie Akcesyjnym okresy na modernizację konwencjonalnych elektrowni, a tylko kilka $\mathrm{z}$ nich przeprowadziło odpowiednie inwestycje $\mathrm{w}$ tym zakresie. Jednocześnie nastąpiła zmiana $\mathrm{w}$ wymogach unijnych odnośnie ochrony środowiska, w tym w zakresie handlu emisjami gazów cieplarnianych. $Z$ tego względu, w wyniku negocjacji założeń dyrektywy dotyczącej handlu emisjami, Polska otrzymała możliwość zastosowania okresu przejściowego $\mathrm{w}$ odniesieniu do obowiązku zakupu przez elektrownie wszystkich uprawnień do emisji gazów cieplarnianych począwszy od 2013 roku. Funkcjonujące w Polsce instalacje, według stanu na 31.12.2008 r., będą nabywały na aukcjach jedynie część potrzebnych uprawnień - 30\% w 2013 roku (w stosunku do średniej emisji z okresu 2005-2007 lub na podstawie wskaźników emisji ważonej rodzajem paliwa). W latach 2014-2019 stopniowo zmniejszana będzie pula darmowych uprawnień, aby w 2020 roku osiągnąć pełny system aukcyjny. Dodatkowo, możliwości pozyskania darmowych uprawnień otrzymają instalacje, wobec których w terminie do 31.12.2008 roku fizycznie rozpoczął się proces inwestycji modernizacyjnych. Przedmiotowy okres przejściowy ma zapobiec eliminacji węgla z portfela paliw pierwotnych, co wpłynęłoby na osłabienie bezpieczeństwa energetycznego Polski. Pozwoli to również na zweryfikowanie możliwości zastosowania klauzuli rewizyjnej w stosunku do założeń pakietu klimatyczno-energetycznego. Derogacje od 100\% zakupu uprawnień do emisji $\mathrm{CO}_{2}$ na aukcji dla elektroenergetyki mogą być przedłużone na okres po 2020 roku. Problem w tym, że z powodu opóźnień w realizacji inwestycji modernizacyjnych oraz mającej obowiązywać od 2013 roku nowej polityki ochrony klimatu, przydzielona elektrowniom liczba uprawnień emisyjnych może być niewystarczająca. Chcąc prowadzić działalność będą one zmuszone do zakupu odpowiedniej ich liczby na giełdzie. Dodatkowy wydatek na zakup uprawnień, obok nakładów na inwestycje modernizacyjne, spowoduje wzrost kosztów wytworzenia energii i ostatecznie jej ceny. Jest to niekorzystne dla jej użytkowników i gospodarki, bo wiąże się z określonymi konsekwencjami społecznymi i ekonomicznymi. Wzrost cen energii (zwłaszcza elektrycznej) dla gospodarstw domowych może spowodować znaczne zmniejszenie

${ }^{13}$ Tak jest np. w przypadku budowy elektrowni węglowych w systemie przygotowanym do wychwytywania $\mathrm{CO}_{2}$. W Polsce dopiero podjęto próbę zbudowania instalacji opierając się na technologii CCS, ale tak naprawdę nie do końca są rozpoznane konsekwencje i/lub skutki magazynowania $\mathrm{CO}_{2}$ czy ewentualnych awarii takich obiektów. Poza tym ta technologia jeszcze nie jest przygotowana $\mathrm{w}$ pełni do komercyjnego zastosowania. 
wielkości popytu na nią z powodu niemożności jej zakupu, co może doprowadzić nawet do tzw. ubóstwa energetycznego. Natomiast w przypadku przedsiębiorstw (zwłaszcza przemysłowych) prowadzi do wzrostu kosztów produkcji i zmniejszenia ich konkurencyjności ${ }^{14}$, a w konsekwencji do zmniejszenia konkurencyjności gospodarki. Nie należy przy tym zapominać, że nadmierny wzrost cen energii „kłóci się” nieco z zasadą zapewnienia dostarczania energii do odbiorców po akceptowanej społecznie cenie ${ }^{15}$. Poza tym wzrost cen energii ponad poziom przekraczający możliwości finansowe odbiorcy nie jest również korzystny dla samych elektrowni, gdyż zmniejszony popyt na energię w skrajnej sytuacji może nawet postawić pod znakiem zapytania dalsze ich funkcjonowanie. W takiej sytuacji ogromnego znaczenia nabiera działalność regulacyjna państwa, zwłaszcza realizowana przez Urząd Regulacji Energetyki, który dbając o bezpieczeństwo energetyczne kraju powinien uwzględniać wszelkiego typu uwarunkowania.

W świetle powyższych uwarunkowań można zauważyć, że proponowane w Polityce energetycznej rozwiązania poszczególnych problemów w sektorze energetycznym nigdy nie są ostateczne i wywołują wiele różnych kontrowersji. Pomimo tego, że rozwiązania te są zgodne $z$ wymogami unijnej polityki energetycznej i ekologicznej to uwydatniają i pogłębiają istniejące problemy wynikające $z$ uwarunkowań historycznych, technologicznych i geopolitycznych. Prowadzi to czasami nawet do wątpliwości czy uda się zrealizować cele i wytyczne tych polityk w kontekście zrównoważonego rozwoju, zwłaszcza w odniesieniu do zagadnień ochrony środowiska naturalnego, gospodarki niskoemisyjnej i bezpieczeństwa energetycznego.

\footnotetext{
${ }^{14}$ Już teraz największe firmy przemysłowe w Europie jednoczą siły, by domagać się rekompensat w związku ze wzrostem cen energii, gdy od 2013 roku zacznie obowiązywać nowa polityka ochrony klimatu. Istniejące w różnych krajach UE zrzeszenia firm energochłonnych chcą wspólnie przekonać Komisję Europejską, by dokonała zmian w przepisach o pomocy publicznej i tym samym umożliwiła rekompensaty. $W$ tej sprawie m.in. rozmawiał z przedstawicielami polskich firm w Warszawie szef International Federation of Industrial Energy Consumers. Chodzi o porozumienie i wspólne wystąpienie organizacji nawet 10 krajów UE, które obawiają się, że z powodu konieczności ograniczenia emisji $\mathrm{CO}_{2} \mathrm{w}$ ramach polityki klimatycznej ceny energii wzrosną tak, że europejski przemysł straci konkurencyjność. Polska, w której ponad 90\% energii pochodzi $z$ węgla jest w trudniejszej sytuacji niż inne państwa unijne, dlatego nasze przedsiębiorstwa są tym żywotnie zainteresowane. Przedsiębiorstwa przemysłowe oczekują, że rząd polski mający formalnie do dyspozycji liczone w miliardach euro kwoty ze sprzedaży pozwoleń na emisję $\mathrm{CO}_{2}$, przeznaczy część tych środków na rekompensaty. Eksperci sugerują, że każde przedsiębiorstwo mogłoby otrzymywać po podsumowaniu roku konkretną kwotę. Zob. A. Łakoma, Potrzebne doptaty do prądu, „Rzeczpospolita” 2011, nr 252(9068).

15 W. Bojarski, Bezpieczeństwo energetyczne, [w:] Wokót energetyki, czerwiec 2004, www.cire.pl (data pobrania: 20.10.2011).
} 


\section{ZAKOŃCZENIE}

Przeprowadzona analiza wybranych związków między celami polityki energetycznej (zwłaszcza zapewnieniem bezpieczeństwa energetycznego) a istniejącymi w Polsce uwarunkowaniami jej realizacji pozwoliła wskazać na pewne problemy i kontrowersje $\mathrm{z}$ tym związane. Kontrowersje tu przedstawione mają charakter ekonomiczny, ekologiczny, społeczny i technologiczny. Ich zlikwidowanie i rozwiązanie istniejących problemów nie jest łatwe, gdyż wymaga podjęcia wielu istotnych decyzji i działań oraz zastosowania odpowiednich instrumentów. Konieczne jest m.in.:

- opracowanie bilansu energetyczno-ekonomicznego dla posiadanych przez nasz kraj nośników energii;

- szybkie przeprowadzenie odpowiednich inwestycji, zarówno modernizacyjnych jak i takich, które zwiększą moce wytwórcze energetyki;

- stworzenie warunków i mechanizmów, które ułatwią energetyce pozyskiwanie środków finansowych na inwestycje;

- zabezpieczenie dostaw energii $\mathrm{z}$ importu;

- zintensyfikowanie prac nad wykorzystaniem technologii CCS;

- przyspieszenie wdrożenia odpowiednich regulacji ze strony państwa.

Pomimo kontrowersji istnieje zgodność, że wytyczone kierunki działań, u podstaw których leży innowacyjność, stwarzają szansę sprostania zagrożeniom wynikającym $z$ istniejących i nowo kształtujących się uwarunkowań oraz pojawiającym się nowym tendencjom.

\section{BIBLIOGRAFIA}

Bojarski W., Bezpieczeństwo energetyczne, [w:] Wokót energetyki, czerwiec 2004, www. cire.pl (data dostępu 20.10.2011).

Energia 2020. Strategia na rzecz konkurencyjnego, zrównoważonego i bezpiecznego sektora energetycznego, $\mathrm{KOM}(2010) 639$ wersja ostateczna. Komisja Wspólnot Europejskich. Europejska polityka energetyczna, Komunikat Komisji do Rady Europy i Parlamentu Europejskiego, Komisja Europejska, Bruksela 10.01.2007, COM 1 wersja ostateczna 2007.

Europejska strategia na rzecz zrównoważonej, konkurencyjnej i bezpiecznej energii. Zielona Ksiegga. Wersja ostateczna, Komisja Europejska, Bruksela 8.03.2006, COM 105.

Europe's Energy Portal, accessed: www.energy.eu (data pobrania 10.10.2011).

Kasztelewicz Z., Zasoby wegla brunatnego w Polsce i perspektywy ich wykorzystania, „Polityka Energetyczna”, t. 11, z. 1, IGSMiE PAN, Kraków 2008.

Łakoma A., Potrzebne doptaty do pradu, „Rzeczpospolita” 2011, nr 252(9068). 
Ochrona środowiska, GUS, Warszawa 2010.

Pakiet klimatyczno-energetyczny. Analityczna ocena propozycji Komisji Europejskiej, Urząd Komitetu Integracji Europejskiej, Departament Polityki Integracyjnej, Warszawa 2008.

Pawłowski A., Uwarunkowania bezpieczeństwa energetycznego Polski a rozwój zrównoważony, [w:] D. Kiełczewski (red.), Implementacyjne aspekty wdrażania zrórwnoważonego rozwoju, Wyd. Wyższej Szkoły Ekonomicznej w Białymstoku, Białystok 2011.

Polityka energetyczna Polski do 2030 roku. Ministerstwo Gospodarki. Załącznik do uchwały nr 202/2009 Rady Ministrów. Warszawa 10.11.2009.

Ustawa Prawo energetyczne, Dz.U. 2006, Nr 89, poz. 625 z późn. zm.

Zaporoski B., Analiza kosztóww wytwarzania energii elektrycznej, t. 11, z. 1, IGSMiE PAN, Kraków 2008.

http//www.pse-operator.pl. (data pobrania 12.10.2011).

http//energetyka.wnp.pl/elektrownie (data pobrania 10.08.2011).

\title{
KONTROWERSJE POLSKIEJ POLITYKI ENERGETYCZNEJ W KONTEKŚCIE REALIZACJI WYMOGÓW UNIJNYCH
}

\section{STRESZCZENIE}

Wiadomo, że we współczesnych gospodarkach jedną z ważniejszych kwestii jest zaopatrzenie w energię i zabezpieczenie jej nośników. Dlatego każde państwo stara się prowadzić swoją politykę energetyczną tak, by zaspokoić istotne potrzeby swojego kraju. Polska polityka energetyczna uwzględnia wymogi unijnej polityki energetycznej i ekologicznej. Jednakże specyfika naszej gospodarki i posiadane zasoby surowców energetycznych wywołują pewne problemy z jej realizacją. Dlatego przeanalizowano wybrane związki między celami polityki energetycznej (zwłaszcza zapewnieniem bezpieczeństwa energetycznego) a istniejącymi w Polsce uwarunkowaniami jej realizacji, co pozwoliło wskazać na pewne problemy i kontrowersje $z$ tym związane. W artykule określono charakter istniejących kontrowersji oraz zasugerowano, co wymaga odpowiednich działań.

\section{CONTROVERSIES OVER POLISH ENERGY POLICY \\ IN THE CONTEXT OF IMPLEMENTING THE EUROPEAN UNION REQUIREMENTS}

\author{
SUMMARY
}

The issues connected with ensuring energy supply and securing its carriers determine the real development opportunities in the future. Therefore, energy policy has been 
developed both at the EU and member states level. Polish energy policy includes the requirements of the EU policy, but the characteristics of our economy and the possessed energy resources cause some problems with its implementation. For this reason, the principal objective of this article is to show the controversies related to the implementation of the Polish energy policy in the context of existing conditions. 